\title{
Entrevista: \\ Milton Meira do Nascimento
}

\author{
Entrevistadores: \\ Camilla Pinetti \\ Dario Galvão \\ Karina Tanada \\ Larissa de Carvalho Nascimento \\ Marcelo Hotimsky \\ Vinícius de Oliveria Prado
}

Para a quinta edição da Revista Humanidades em Diálogo, entrevistamos o professor e filósofo Milton Meira do Nascimento. Graduado em filosofia pela Universidade de São Paulo em I97I, fez seu mestrado, doutorado e livre-docência na mesma instituição, na qual é professor titular de Ética e Filosofia Política desde 2006.

Nesta entrevista extremamente descontraída realizada na tarde do dia 29 de agosto de 20I3, o professor contou de sua trajetória intelectual e comentou a situação política atual, diagnosticando uma crise intensa de representação presente na origem dos protestos que vem ocorrendo no país desde junho desse ano. Sempre com uma postura crítica, Milton Meira utiliza de toda a tradição da filosofia política, de Rousseau a Agamben, para pensar os problemas da atualidade, buscando compreender as possibilidades de participação política presentes nas lutas de hoje, seja nas ruas de todo o país, seja nos corredores do departamento de filosofia da USP. 
Humanidades em Diálogo: Como o senhor descreveria sua trajetória intelectual? Quais obras e pensadores o influenciaram? E quais questões orientaram as escolhas de sua produção acadêmica?

Milton Meira: Nos anos 6o, antes de ingressar na faculdade, o meu campo de interesse era a literatura contemporânea. Lia, sobretudo, textos de Sartre e Camus, como A náusea e Aidade da razão. Como eu trabalhava o dia inteiro e estudava à noite, aproveitava o período noturno para entrar em contato com o pessoal do cursinho do grêmio (que hoje seria o CAF [Centro Acadêmico de Filosofia]), que trabalhava na filosofia. Tive contato também com os artistas que frequentavam a região da Maria Antônia, como [Geraldo] Vandré, Ghico [Buarque], Gaetano [Veloso]... Nessa região, havia uma circulação bastante ampla, de pessoas da filosofia e de outras áreas. Fui me inteirando sobre filosofia e comecei a ler os textos de Descartes e Husserl. Mas minha principal motivação para entrar na filosofia foi Sartre, me interessava por uma filosofia mais engajada, e talvez mesmo pelo existencialismo.

Agora, quanto à trajetória intelectual, entrei na filosofia num ano muito conturbado, que foi I968. Praticamente um ano inacabado, não é? No final de I968, houve aquela briga na Maria Antônia, com o pessoal do Mackenzie. Nessa época eu comecei a dar aula de filosofia num supletivo. Depois passei para outro colégio, o Equipe, que tinha uma experiência didática muito interessante.

Então, meu interesse inicial pela filosofia foi para ser professor do Ensino Médio. Eu comecei a trabalhar no supletivo e depois no Equipe. Nós produzíamos apostilas e outros materiais didáticos, mas tínhamos como principal objetivo trabalhar a filosofia no Ensino Médio com professores de outras áreas: história, português, ciências. Nossa intenção era fazer com que a Filosofia fosse um centro de diálogo para tentar formar nos alunos um interesse por essa disciplina, não em uma abordagem técnica, e sim uma formação mais aberta, mais abrangente. Dessa forma, sugeríamos temas de dissertação que às vezes envolviam história, ciência e literatura. Criamos um jornal lá dentro, no qual os alunos podiam escrever textos de filosofia, história e outras disciplinas.

Quando comecei não tinha projeto de mestrado e doutorado. Estava apenas saindo do jornalismo. Eu trabalhei na revista Visão, não sei se vocês já ouviram falar... A revista Visão é muito parecida com o que hoje é a Veja e a IstoÉ, mas bem melhor. Era uma revista muito investigativa, entrei lá depois que passei pela Imprensa Oficial do Estado como revisor. Continuei com os dois empregos e ainda dando aula no colégio Equipe. Eram três empregos com carteira assinada. Trabalhava das sete às nove no Equipe, das nove e meia às cinco na revista Visão e das sete e meia à uma da madrugada na Imprensa 
Oficial do Estado. Quando olho minha carteira de trabalho, não sei como eu conseguia fazer tudo isso (risos). Eu já estava fazendo esses trabalhos para o Ensino Médio e fui pegando gosto pelo ensino da filosofia para a molecada que tinha entusiasmo. Mais tarde, em I975, o professor [Oswaldo] Porchat convidou vários professores para a Unicamp e houve várias vagas aqui [na USP], então eu entrei em uma dessas vagas. Eu, a Lygia Watanabe, o Mário Miranda... Nesse grupo, todos são praticamente da mesma época, da mesma turma. Carlos Alberto [Ribeiro de Moura], Luís Henrique [Lopes dos Santos], Franklin Leopoldo [e Silva], Olgária [Matos], Scarlett [Marton], Mário Miranda, Maria das Graças [de Souza]... Nós éramos praticamente do mesmo ano e frequentamos os mesmos cursos na graduação.

Meu interesse mais acadêmico pela filosofia começou com o Ensino Médio. Depois, segue com o contato com o [Roberto] Salinas [Fortes], que estudava Rousseau. Então, em I974, comecei a me entusiasmar e decidi fazer um projeto de mestrado, também sobre Rousseau. Eu achava que esse filósofo era importante para pensar a política daquele período. Esse é o início, depois têm os desdobramentos... (risos).

Humanidades em DiÁlogo: O que o senhor pensa a respeito das manifestações do último mês de junho, que levaram milhões de pessoas às ruas em diversas cidades do país? Qual seria o significado desses eventos do ponto de vista da história da política brasileira?

Milton Meira: A impressão que eu tenho é que isso se deve a um processo longo de distanciamento da estrutura, da classe, da representação política dos representados. Esse abismo que existe entre a vida política e a sociedade civil é o elemento mais importante que desencadeia e vai continuar desencadeando protestos e outras formas de manifestação, que podem ser chocantes ou inusitadas, mas são resultado, a meu ver, de uma falência total do sistema de representação política. A nossa democracia representativa, não só no Brasil como no mundo inteiro, passa por um processo bastante desgastante que atesta exatamente a distância entre o quadro dos representantes e o dos representados.

Será necessário, talvez, repensar totalmente esse sistema. Encaminharia mais para aquilo que alguns autores vêm trabalhando hoje: uma sociedade civil forte e uma vida política que a englobe como ação política também. Uma visão completamente diferente da política que nós temos, a chamada democracia representativa. Mas isso evidentemente implica em apostar que a sociedade civil possa fazer projetos, desenvolver atividades, que são atividades de caráter público, não estatal. 
A sociedade civil organizada pode, por exemplo, desenvolver projetos de educação, saúde, saneamento básico, construção de moradia popular e por aí vai. Tudo que o Estado faz hoje, a sociedade civil pode fazer por iniciativa própria. Quando a sociedade civil não se organiza, é como se a vida que levamos na nossa atividade profissional estivesse totalmente distanciada da instância que decide sobre a nossa vida. Esse distanciamento vai levando, cada vez mais, à percepção de que as coisas acontecem aqui e que a vida política tem outro mundo completamente diferente. Eles [a classe política] agem como se a gente não existisse e não tivesse nenhum conhecimento do que está acontecendo em todos os níveis. Sabem o que está acontecendo, mas não têm a capacidade de mobilizar a sociedade civil para tomar decisões, agir e ter projetos que se concretizem. Nada acontece, as decisões são lentas demais, projetos ficam engavetados... Então, os protestos têm como origem, no núcleo central, esse afastamento entre a classe política e a base dos representados. Enquanto isso continuar a movimentação vai persistir porque é um processo que atesta a falência da nossa democracia representativa.

Agora, é claro que reformas políticas são possíveis, então você vai tentar aproximar os representantes dos representados. Essa aproximação, a meu ver, se dá se houver uma mobilização muito forte da chamada sociedade civil, fazendo projetos.

Nisso, percebemos também que uma universidade como a nossa está mais ou menos falida, não é? O projeto de universidade que nós temos. É estatal, mas poderia ser também iniciativa da sociedade civil. A sociedade civil pode se mobilizar e criar uma universidade pública, por exemplo.

\section{Humanidades em Diálogo: Mas como isso se daria, como seria essa so- ciedade civil organizada?}

Milton Meira: Você pode fazer projetos, só que os recursos são recursos públicos, não da iniciativa privada. Podemos, por exemplo, montar um grupo com o objetivo de fazer uma urbanização na favela São Remo. Vamos esperar que a prefeitura tome uma decisão dessa? Se for uma decisão governamental ela vêm da prefeitura. Mas a sociedade pode se organizar para criar uma entidade com um objetivo, que pode ser pontual. Para isso, é preciso montar uma estrutura, uma organização com personalidade jurídica e que vai ter os recursos públicos que vão ser aplicados para a urbanização da favela. É possível também fazer convênios com a iniciativa privada.

Mas essa iniciativa vem da sociedade civil, não vêm do aparato estatal. Porque quando pedimos ao poder executivo que realize projetos, temos sempre 
a dependência de uma estrutura centralizada, que vai, se for o caso e houver recursos, se mobilizar para atender às múltiplas reivindicações, em geral de partidos, ligadas a vereadores e, longinquamente, a associações de base. Então esse processo é interessante porque você muda a perspectiva e dá à sociedade civil a condição de ser um agente importante, político. Porque fazer política não é só dentro do partido ou nas instâncias como Congresso, Câmara de Vereadores e Assembleia Legislativa.

\section{HuMANIDADES EM DIÁlOGO: É factível conseguir recursos na atual situa- ção política?}

Milton Meira: Sim, porque já temos legislação que permite que a sociedade civil se organize e faça parcerias com o Estado para que haja recursos para viabilizar esses projetos, só que isso não está posto em prática. As pessoas não se dão conta de que existe essa possibilidade. O mecanismo é sempre pedir à administração pública, aos governantes que concedam recursos aos projetos. E, como é sempre assim, entra em jogo uma espécie de barganha política, eles fazem hospitais, creches, mas isso é prática eleitoreira. Agora, quando a sociedade civil se organiza, tem projetos e propostas, isso muda completamente o quadro, ela se torna uma entidade política, um agente político importante.

O grande tabu da política, a meu ver, aliás, da contemporaneidade, é separar: a sociedade civil, o lugar onde se desenvolve a atividade particular, de interesse privado, e a área estatal onde se desenvolve o interesse público. Isso é um absurdo tão grande, pois na sociedade civil aquilo que nós fazemos tem interesse público. Celulares, sapatos, são todos instrumentos que estão no mercado, mas que são de interesse público.

Então, vocês me perguntaram sobre a questão dos movimentos sociais... atualmente eles se dão porque a sociedade civil, descontente com a classe política, reclama. Reclama e consegue alguma coisa, por exemplo, a manutenção do preço do ônibus e do metrô. Mas essa prática de reclamar para a instância que detém todos os recursos, todos os meios para viabilizar qualquer coisa, funciona da mesma maneira, ou seja, não tem nada de novo. Você pode ficar batendo na porta até conseguir. Mas ao fazer isso você reforça uma estrutura política centralizada. É claro que isso é um sintoma, mas a via política me parece que não é essa. Ora, o governo não é dono de nada. É a mesma coisa quando você vai bater à porta do reitor para obter um monte de coisa. Isso é ridículo! Por que, que tipo de poder é esse? Quando a sociedade está toda estruturada em formas e poderes centraliza- 
dos, haverá sempre esse tipo de manifestação. Agora os alunos vão começar a reclamar para pedir democratização, não é? A ADUSP foi barrada na porta de entrada do gabinete do reitor na semana passada, para falar sobre inclusão na pauta do Conselho Universitário. Mas as mobilizações vão continuar e é bom que continuem, porque isso dá um diagnóstico da falência do sistema representativo.

Humanidades em Diálogo: No quesito novidade, não haveria nestas manifestações algo de novo no fato de elas não serem, em grande maioria, centralizadas e postas de uma maneira vertical? Além disso, observa-se a presença de pessoas de inúmeras classes sociais e de distintas esferas da sociedade. Fala-se em falta de unidade nestes movimentos, é possível pensar em unidade?

Milton Meira: Bom, teve novidade sim, porque a mobilização não foi feita da forma tradicional através de lideranças sindicais, lideranças partidárias. Foi um processo realizado com a utilização dos meios de comunicação e das redes sociais. O que, de certa maneira, atesta um descontentamento disseminado, que não possui um perfil definido. Cada um vai à rua reivindicar seu descontentamento com alguma coisa. Pode ser transporte, saúde, educação etc. Esse descontentamento, multifacetado, não tem perfil de ser passível de mobilização de uma liderança partidária qualquer, mesmo de liderança sindical. Ela vem da própria rede de comunicação e essa é a novidade. Isso mostra também que a força de mobilização que existe hoje da sociedade civil é muito mais forte para a obtenção de objetivos como esses que eu citei, de criar estruturas de organização diferentes da área estatal. Hoje nós temos meios, pois possuímos tecnologia para fazer isso. Você pode mobilizar um bairro inteiro utilizando redes sociais e daqui a pouco está todo mundo na pracinha do bairro para conversar. E qualquer coisa que venha a ser organizada pode ser feita nas redes sociais. É muito mais fácil organizar a comunidade do que esperar que haja uma liderança, visto que a questão das lideranças, no mundo moderno, vai mudar de figura. Não precisa haver nenhuma liderança carismática, talvez haja múltiplas lideranças. E lideranças que não são permanentes, que são passageiras, apenas a fim de se mobilizar tendo em vista um objetivo preciso. E também não há necessidade, pois o importante é que se concretizem certos objetivos.

Humanidades em Diálogo: Trata-se de uma espécie de reforço do aspecto plural da política? 
Milton Meira: Exatamente. Ao invés de termos uma classe política cujo interesse público é discutido apenas por ela, e aqueles que delegaram o voto não fazem mais nada nesse interregno do processo da política, teremos o contrário: a sociedade civil é que vai fazer política. Não é uma classe específica que tem partidos etc., por isso é preciso reestruturar tudo, porque apareceram muitas pessoas ali que não tinham interesse algum em estar vinculado a algum tipo de partido.

Humanidades em DiÁlogo: Nessa perspectiva, poder-se-ia explicar por que muitos partidos de esquerda radicais criticam os movimentos atuais por terem como fim reformas e não uma revolução, advindo de um movimento socialista etc.? Nessa via, pode-se perguntar também por que esse fim está tão em crise atualmente?

Milton Meira: É porque essa estrutura de representação, a qual eu me referi, é tanto de esquerda quanto de direita, porque reforça uma relação paternalista, uma infantilização das pessoas, que têm de correr atrás de lideranças. Outra questão também é: por que o movimento estudantil é fraco? Ele se mobiliza, sim, com uns gatos pingados que fazem muito barulho. A grande maioria dos estudantes está totalmente afastada da política estudantil, no entanto, eles se apresentam como representantes da categoria estudantil. Mas o distanciamento que existe é muito grande: da representação estudantil à grande massa dos estudantes. Por quê? Porque a concepção de política dos grupos de liderança é a mesma. Então, "nós temos que mobilizar", "nós temos que ser a vanguarda revolucionária", "nós temos que ser a vanguarda dirigente" e os outros vão ser todos massa de manobra, como carneiros. Então, você tem uma infantilização também do movimento estudantil, de todos os estudantes que não são aqueles que participam das lideranças e das entidades que comandam a vida política oficial do movimento estudantil. Será que é apatia ou é um distanciamento completo da grande maioria? Será que todo estudante da USP ou 90\% são todos apolíticos, infantilizados, imbecilizados? É difícil de acreditar. Eu não acredito nisso. Eu acredito muito mais na existência de um distanciamento completo da representação.

Humanidades em DiÁlogo: Seria um problema situar a representação como algo que não está conseguindo ser efetivado? Ou seria um problema da natureza de um sistema que se baseia num ponto de vista representativo? Representação em si como base de uma estruturação política, de uma comunidade política, relacionado a um Estado civil, é um problema? 
Milton Meira: Bom, depende da forma de representação. Você pode ter um representante, com a condição de que ele tenha mecanismos de prestar contas da sua representação, daquilo que faz; e o representado, por sua vez, tem que ter mecanismos de vigilância, de cobrança etc. Vou dar um exemplo: se mudássemos na legislação política atual a forma de cassação de mandatos de deputados. Por que, em vez de o congresso cassar, o eleitor não pode cassar? Cria-se uma legislação para aqueles que votaram possam cassar o mandato do deputado. Ontem [28/08/20I3] não houve aquela votação escandalosa, na qual [Natan] Donadon foi condenado e continua no congresso, mesmo tendo sido cassado? Por que isso acontece? Porque o Congresso é uma corporação fechada, eles vão se proteger. Mas, se o eleitor tivesse oportunidade de se manifestar, por exemplo: com tantas assinaturas você cassa um deputado. Mudaria completamente essa relação. Atualmente, o representante vive como se estivesse tão distante, como se tivesse uma vida própria. Não é assim. Representante tem de prestar contas do que ele faz pelos representados a todo instante.

\section{Humanidades em DiÁlogo: Ainda sobre as manifestações, o que o senhor acha que os livros de história dirão sobre o período em que vivemos?}

Milton Meira: Bem, analisando de um ponto de vista tradicional, nós participamos dos protestos contra a ditadura militar, depois houve em I984 a movimentação pelas Diretas Já!, tinha muito mais gente na rua do que houve nessas manifestações agora. Eu me lembro que participei de manifestações no Anhangabaú com I milhão de pessoas, Franco Montoro, Ulisses Guimarães, o Anhangabaú inteiro lotado. Mas ali era uma mobilização para eleição direta para presidente da república. Todo mundo estava empenhado nisso. E depois veio a decepção total, a eleição foi indireta e não direta, na qual Tancredo Neves ganhou, para sorte, pois poderia haver coisa pior. Então, com Tancredo ganhando a eleição, houve, paradoxalmente, uma distensão. Ele era um cara de oposição, participou das Diretas e foi eleito. Ganhou o candidato que ganharia, caso houvesse eleições diretas. Mas agora, o movimento atual não tem um perfil... o que mudou, é que houve um enfraquecimento da vida política tradicional e uma indicação de que a coisa não vai continuar da forma como está e se não houver uma reforma política pra valer, a coisa vai ficar muito difícil.

Então isso exige uma reflexão geral de mudança radical. Só que a classe política não percebeu isso, ou seja, que a sociedade indica que não dá pra continuar num modelo completamente falido de política. E isso pode piorar bastante. 
Humanidades em Diálogo: Houve algumas respostas...

Milton Meira: Respostas muito pontuais, não é? Reformas muito pequenas, muito tímidas.

Humanidades em DiÁlogo: Mas o senhor é otimista em relação à classe política?

Milton Meira: Não, pelo contrário. Eu sou otimista em relação à mobilização da sociedade civil. A classe política vai se defender.

Humanidades em Diálogo: O que o senhor, como leitor da tradição crítica dos direitos humanos, poderia nos dizer acerca das múltiplas e bandeiras que se põem atualmente, como movimento negro, feminista, gay etc., que de certa forma estiveram presentes também nas manifestações?

Milton Meira: São todos movimentos das minorias, totalmente legítimos dentro da perspectiva clássica da bandeira dos direitos humanos. Mas o movimento tem como projeto final o reconhecimento da estância estatal da sua própria condição. É preciso se mobilizar para ter o reconhecimento oficial, como já se tem com o casamento gay. Praticamente quase nada é contemplado hoje pela legislação. Todos os movimentos de minorias, que eram movimentos de direitos humanos, passam a ser hoje de direitos civis. Aliás, o objetivo dos movimentos pelos direitos humanos é a transformação dos direitos civis.

O mais interessante seria estabelecer um processo contínuo, aquilo que Glaude Lefort chamaria de criação de novos direitos. A cada momento em que se apresentam situações novas deve haver um processo democrático de criação de novos direitos (mas não dentro da estrutura que nós temos de democracia representativa). E isso evidentemente requer a mobilização constante da sociedade civil em função da possibilidade de novos direitos.

Mas, ao invés da bandeira dos direitos humanos ser cristalizada e universalista, ela é uma bandeira muito fluida, muito rápida, ou seja, uma vez contemplada na legislação ela praticamente deixa de existir. Há uma diferença entre o ser contemplado pela estância estatal e transformar reivindicações em leis. Lei Maria da Penha, casamento gay, cotas nas universidades, são formas de estabelecimento de direitos civis que são direitos do cidadão. E a partir do momento que são direitos do cidadão não são mais universais, não tem mais a pretensão de universalidade, estão enquadrados dentro da legislação. Resta saber se nesse processo chegamos àquilo que seria um processo de dominação 
total de todas as instâncias, até a intimidade, estabelecida em lei, dizendo o que você pode ou não pode fazer, o reverso da medalha. Em vez de libertação temos dominação total na medida em que tudo pode ser decodificado em lei. Aí não se teria nenhum espaço mais para a individualidade, no sentido da intimidade. Tudo é regulamentado. Esse é o outro lado, o reverso da reivindicação dos direitos. Existe um lado interessante que é o reconhecimento das peculiaridades e das demandas particulares. Por outro lado, a assimilação na instância estatal de toda e qualquer esfera individual e particular, o que daria no reverso: fim da liberdade, fim de todos os direitos.

\section{Humanidades em DiÁlogo: Mas você acha que essa é uma via de mão única, como Agamben acha, por exemplo?}

Milton Meira: É exagerado dizer que não temos saída. Temos saída se houver algumas esferas que não se tenha interesse algum de que o Estado interfira, no que você faz ou deixa de fazer. Desde que não coloque em risco a própria estabilidade da vida comunitária da sociedade, isso é permitido. Mas isso já estava em Hobbes, já estava em Rousseau. O que as pessoas fazem na sua particularidade que não é interessante para a constituição da soberania, é o que sobra da liberdade particular para cada um. Mas a liberdade particular não se reivindica, ela já está posta. Você reivindica que o Estado não interfira mais.

Quando você diz que o Estado não deve interferir mais, você também não reivindica mais, percebeu o outro lado? Pois se reivindicar, você quer reconhecimento estatal e jurídico. Então fica sossegado, não reivindica coisa alguma, porque se você reivindicar o Estado captura. Por isso o Agamben diz que é o reverso e o Estado nazista é o resultado desse movimento. No Homo Sacer ele diz que o nazismo é a forma acabada do processo de reivindicação dos direitos até chegar aos direitos nacionais, de um cidadão que reivindica o sangue e solo, nasceu e tem o mesmo sangue, deve ser um cidadão alemão e quem não for tem que ser espirrado.

Agora, tem muitas coisas também que eu não acredito que sejam interessantes.

\section{Humanidades em Diálogo: Por exemplo?}

Milton Meira: Por exemplo, a reivindicação de cotas raciais é um equívoco total. Poderia até se admitir, mas de maneira provisória, cotas de caráter social, mas cotas raciais não fazem sentido. A cota racial na verdade é discriminatória. O processo de socialização deve ser de integração, não de segregação e quando você estabelece cotas, você segrega. Entrar na USP por meio de cotas 
faz com que a pessoa já esteja estigmatizada numa universidade de elite. Então, as cotas de ingresso são canoas furadas. Quer dizer, nós estamos numa canoa furada porque esse estilo de universidade também vai acabar logo. É um absurdo que todo mundo no Brasil queira fazer universidade a qualquer custo. Então o governo dá bolsa para o aluno entrar numa faculdade que não ensina coisa alguma. Isso é dinheiro público jogado fora e é iludir os estudantes que pensam que estão aprendendo alguma coisa, mas não estão aprendendo nada. Ilusão total. Agora você vai dar bolsa? E além de bolsas, cotas? Devia entrar na universidade quem de fato quer, mas para isso seria necessário ampliar vagas públicas para todos e pronto. Mas esse é um longo papo que a gente precisaria ter sobre universidade, cotas...

Humanidades em DiÁlogo: Gostaríamos de fazer algumas perguntas a respeito da sua obra Opinião pública e revolução. Em primeiro lugar, qual a razão do senhor ter escolhido como objeto de estudo justamente o Círculo Social, esse grupo tão peculiar no período revolucionário da França?

Milton Meira: Em I978, eu fui para Paris pesquisar e estudar com o professor Yvon Belaval, um grande conhecedor de Descartes, Leibniz, cuja obra na história da filosofia é bastante abrangente. Ele era uma figura muito interessante, muito aberta, com quem eu conversava muito. Ele me apresentou a alguns professores que trabalhavam com Rousseau. Nessa época eu tive contato também com os trabalhos do Michel Villey, professor da faculdade de direito e muito amigo do Belaval.

Belavalle se aposentou e eu fui estudar na École des Hautes Études com Jean Marie Goulemont, que escreveu recentemente L'Amour des bibliothèques, um texto maravilhoso. Ele, que até hoje é um frequentador da Biblioteca Nacional de Paris, faz uma reflexão sobre os frequentadores das bibliotecas: lugares onde se encontram todos os loucos da França. Inclusive nós também estamos lá (risos).

Esse foi meu orientador depois que o Belaval se aposentou. Ele tinha um trabalho muito importante sobre Will Eisner e a estética da recepção e foi ele quem mostrou a importância da recepção do texto. Goulemont também me apresentou a Roger Barnier, que tinha feito uma tese de oito volumes sobre Rousseau durante a revolução. Barnier me passou seu material de pesquisa, que eu reproduzi em microfilme (hoje está tudo disponível na Gallica).

Comecei a ler os textos e me interessei pelo Círculo Social ter Rousseau como seu patrono, e pelas 2I conferências que o Abade Fauchet fez sobre o 
Contrato social. Roger Barnier tinha feito um parágrafo também sobre o Círculo Social, mas de maneira muito rápida. Então eu fui ler todos os I24 números do jornal Bouche de Fer, depois todos os outros jornais que eram dos departamentos, algumas revistas também, uma produção fascinante no período de dois anos. E tudo isso na Biblioteca Nacional, eu ficava lá das nove da manhã às seis da tarde todos os dias. Fui lendo a recepção do Rousseau na Revolução Francesa e ao mesmo tempo pensando a relação dos intelectuais com a política. A questão importante é a vida política, a ação política, precisando se justificar teoricamente e para isso busca nos autores uma espécie de reforço da prática. Você busca a autoridade pra dizer "Rousseau é essa figura importante, escreveu isso e aquilo, e por isso ele deve ser reverenciado por nós”. Mas o Abade Fauchet ia além disso, ele mudava o próprio texto do Rousseau, interferia no Contrato social dizendo assim "isso aqui, se o Rousseau tivesse vivido até agora, ele teria escrito de maneira diferente, teria escrito outra coisa. Mas nós devemos perdoá-lo porque ele não está aqui". Temos o que é o trabalho em filosofia, sobretudo com o texto político: ele nunca seria passível de uma leitura estrutural da maneira como nós estávamos acostumados a fazer com Gueroult, Goldsmtih; porque o leitor tritura o texto, recorta o texto, e todos os intérpretes do Rousseau vão fazendo recortes e recortes e daí surgem múltiplas leituras do mesmo texto, completamente antagônicas umas às outras, e que revelam, na verdade, o leitor, não o autor. Isso é interessante. Então, percebemos que essa é uma estratégia do próprio Rousseau, de escritor também, ou seja, o texto não é exatamente um texto para ser passado como doutrina. Se for doutrina, tudo que está no texto você tem que assimilar e responder igualmente, é como se você fosse adepto de uma seita evangélica, então tem que ler as escrituras sem mudar uma letra. Muita gente entende que a filosofia tem que ser assim: o autor falou, você tem que procurar a interpretação melhor possível, a aproximação, e não pode fugir daquilo, deve-se fazer uma análise estrutural do texto, fora de qualquer contexto histórico, fora de qualquer relação com a vida do autor. A obra de Rousseau tem a presença da vida dele, da história, a interferência de todos os leitores. É um texto que vai ser sempre triturado. O processo antropofágico (risos) da obra do autor se dá assim. Isso aconteceu com Maquiavel também.

Então, como é que eu iria fazer uma leitura estrutural do texto para entender o que ele quer dizer? Ele mesmo é cheio de contradições, cheio de paradoxos como ele dizia, o que permite que o leitor se ponha a pensar. O meu interesse foi muito mais romper com uma tradição do departamento, que era a tradição estrutural: se você lê Descartes, tem que ler o Descartes segundo Gueroult, ou então podia ler o Rousseau segundo Goldsmith, que é 
uma coisa bem certinha e não foge dessa tradição. Mas o Contrato é muito mais do que isso, essa leitura não é suficiente. O Contrato social tem uma história de recepção desde 1762 e continua tendo a sua recepção a cada momento, porque ele desperta no leitor a reflexão. Então eu me pus a pensar: Opinião pública e revolução é o processo segundo o qual os revolucionários franceses tomam o conceito de opinião pública, que é de Rousseau, e assumem a tarefa deles, de se apresentarem como os próprios legisladores em ação. Eles são os legisladores do Contrato, em ação, e tendo a opinião pública como objetivo maior de formação da opinião, modelar essa opinião para exercício da soberania. Têm algumas coisas interessantes que o Abade Fauchet retira exatamente do texto "Do legislador" do Contrato social, e outras que ele vai mobilizando, por conta própria, e tentando apresentar a própria filosofia, e os filósofos que ele convida para participar do Gírculo Social, como os legisladores do mundo moderno. Sim, é o filósofo o legislador, aquele que tenha compromisso com a busca da verdade, não que tenha a verdade pronta. E aí entra outro problema: por vezes essa verdade se cristaliza, ela engessa o processo político. Como no caso dos outros intérpretes de Rousseau, por exemplo, Robespierre que o assimila ao pé da letra: se alguém se recusar, será forçado a ser livre ou será morto. Temos aí um terror revolucionário que é o despotismo da liberdade, também com fundamento no texto de Rousseau, segundo interpretação de Robespierre. Há uma verdade engessada que funciona como terror. É a morte: quem é contra a revolução, quem é contra a liberdade, tem que morrer. É o que Hegel já havia apontado que, quando a filosofia vem do céu à terra, vem sob forma de destruição, se referindo a essa ideia de que, se a liberdade é uma forma cristalizada, quem é contra a liberdade tem que morrer. Mas havia muito disso no século XVIII: cristaliza-se a filosofia como lugar das verdades prontas e acabadas, descobertas pelos filósofos; estes descobriram tudo que existe de importante e aos políticos resta realizar aquilo que já está posto como verdade no plano teórico. A Revolução Francesa é mais ou menos assim. É fascinante, não é? Você olha todos esses aspectos e entende como é difícil trabalhar os textos de filosofia política, porque não são textos fechados, que terminam em si mesmos, mas que mobilizam muitas leituras de todos os tipos. Há também a percepção da interação do próprio texto com o momento do seu lançamento, das questões religiosas envolvidas ali, em Genebra, em Paris, a crítica de Rousseau aos padres. Eu me entusiasmei muito pelo Abade Fauchet, por esse caráter militante da filosofia. É um processo que transforma a filosofia numa ferramenta importante para mobilização na cena política. A política não é por si só suficiente então ela invoca os textos clássicos, como Locke, tratando do que é o estado de natureza, o Estado geral, o governo, a democracia, 
a monarquia (é um verme que corrói a República) e assim vai. É uma espécie de cartilha que era passada como catecismo do povo livre, que trazia todas as supostas verdades que Locke descobriu, Mably, Rousseau, Montesquieu. Vira uma coisa teológica. E é dessa vertente que surgem os direitos humanos como verdades incontestáveis, cristalizações. Vira religião. Esse é o aspecto que eu não gosto dos direitos humanos. Você transforma princípios de sua bandeira em verdades eternas, imutáveis e inquestionáveis, princípios indiscutíveis.

Humanidades em DiÁlogo: Com relação à conclusão dessa sua obra, o senhor dá a entender uma chave argumentativa que dialoga com Hannah Arendt, que a política deve ser pensada como lugar do conflito e tentativa de administração do conflito. A questão é: o que diferencia propriamente a supressão de um conflito e a sua administração? Até que ponto a administração do conflito ela mesma não caracteriza aquilo que se quer evitar na política, que ela seja um todo homogêneo ao invés do campo de batalha que se espera?

Milton Meira: Não, não. Quando a política é um campo homogêneo, é porque esse campo foi produzido por uma forma de entender a política a partir de uma verdade cristalizada. Então, se a filosofia é considerada um corpo doutrinário cristalizado, ela engessa a política e não permite que haja multiplicidade de opiniões. Isso quando a filosofia interfere como uma verdade de caráter teológico. Se você tiver uma sociedade fundamentalista, a política é engessada pela doutrina religiosa. No final, essa é a diferença: reconhecer que há conflitos na sociedade. Mas a política que invoca a filosofia, como base de referência e verdades cristalizadas que interferem na prática, não permite a multiplicidade de opiniões e a efervescência típica da vida política, ou seja, a expressão das diferenças que nós temos. Porque toda e qualquer prática militante tem esse caráter de engessamento da realidade. Se você é um marxista, você engessa a realidade, se é evangélico e vai fazer parte da bancada evangélica na Câmara ou no Senado, você engessa a prática política em função de certos princípios. Então, a militância política é sempre bitolada; refiro-me à militância clássica, no sentido de que você tem um quadro de doutrinas, se aferra a ele e age sempre em função de uma verdade doutrinária que não discute, não questiona. Aliás, é tabu, não se pode questionar, se você é um marxista ortodoxo, não tem discussão. No meu tempo de estudante, líamos o Capital, o 18 Brumário, no primeiro ano todos tinham que ler o Capital aqui no departamento. O contato com esses textos era fascinante. Mas, por outro lado, o viés marxista militante era uma coisa terrível, era muito estreito, bitolado. É por 
isso que quando eu falo da questão política na Revolução Francesa (eu poderia até desenvolver isso, não desenvolvi depois) é para mostrar que qualquer prática militante política que tem esse caráter, como tinha o Gírculo Social, passa a ser uma coisa completamente engessadora da realidade política e não há lugar para a diferença. Claro que a leitura que eles fazem de Rousseau se presta a isto: quando Rousseau não fala coisas que eles consideram interessante, é preciso mudar. Então a gente vai alterando o texto, ou dando uma forma diferente, reconhecendo a autoridade e a mantendo, mas como se fosse um discípulo que continua a obra e a adapta para o presente. Mas isso é praticamente religioso, não é? É esse o sentido da introdução da Hannah Arendt, que pensa política como vida ativa, nessa ideia contemporânea de mobilização da sociedade civil. A ação política para ela não é a dos partidos oficiais, mas a ação política que se desenvolve fora, na sociedade civil, que tem esse caráter político importante, que é preciso ser mobilizado.

\section{Humanidades em Diálogo: A partir de sua experiência como professor e chefe de departamento da Filosofia da USP, qual é a sua opinião a respeito do ambiente acadêmico em geral?}

Milton Meira: Acho que o ambiente acadêmico mudou muito, sobretudo pela ausência do debate. Noto que os estudantes têm pouco espaço para isso. E também têm pouco espaço para a convivência com outras áreas, por exemplo, cinema, literatura, artes, teatro. É como se aqui [na USP] cada instituto fosse uma comunidade isolada, que não se comunica. Isso é muito ruim para a filosofia.

O ambiente foi se transformando porque o próprio processo de pesquisa acadêmica ficou muito fechado também. Na iniciação você estuda Rousseau e vai estudar Rousseau até o doutorado. Mas isso é muito empobrecedor para quem faz filosofia, você pode até ter um autor como referência, mas é preciso arejar um pouco mais. Eventualmente, pode ser preferível escolher um tema e desenvolvê-lo em vários autores do que escolher só um e fazer tudo girar em torno dele.

Mas a própria estrutura acadêmica de departamento incentiva esse tipo de pesquisador, que é contemplado com bolsas. Quem não faz isso tende a ficar de fora. De tal maneira que o que pode melhorar esse quadro é a mobilização estudantil, a sociedade civil organizada dos estudantes, e não a mobilização política dos estudantes tal como se faz no modelo atual. Os alunos têm que se mobilizar para criar instâncias de debate, discussão, apresentação de temas, mesmo dos seus autores, da sua pesquisa individual. Ao fazer isso, estariam 
trabalhando em uma organização que é para-acadêmica, quer dizer, está fora, mas ao mesmo tempo ao lado da academia. Isso deveria ter uma importância dentro da estrutura acadêmica, ter valor institucional do ponto de vista do seu currículo de formação - créditos, dispensa de disciplinas -, porque você está fazendo uma coisa a mais, está gastando tempo para pensar e escrever, e para organizar algo, para mobilizar pessoas, discutir, conversar - produzir uma revista, por exemplo -, mas não tem. Isso serve para a Capes, para pôr no currículo Lattes, mas não tem peso institucional, na estrutura interna do departamento. Há uma estrutura oficial e uma mais ou menos em paralelo que funciona como vocês fazem. Isso é mais um sintoma de que a coisa não vai bem. Vida acadêmica atualmente, considerando apenas o que é institucionalizado, é muito pobre. A instituição mata toda e qualquer possibilidade de invenção que o estudante poderia ter. A academia, a universidade, tem que ser um espaço de criação do conhecimento, e não de repetição. A universidade que repete tudo o que já está posto está falida, praticamente tem seus dias contados. Resta construirmos uma universidade de criação e, no caso da filosofia, de reflexão, é necessário ter essa autonomia e essa ousadia de pensar. É claro que a história da filosofia nos ajuda a pensar, mas ela não é o objetivo do curso, o texto não é o objetivo final do curso, é o ponto de referência para o trabalho de reflexão. Se pensarmos assim, a nossa situação institucional é muito ruim, muito precária, mas quando a gente propõe mudar isso de dentro da faculdade a resistência dos próprios professores, é muito grande, porque é muito mais interessante fazer o feijão com arroz da filosofia - ler alguns autores, mostrar que sabe sobre o autor - do que contestar um autor. Ou fazer como o professor Porchat aconselhava: "Você tem que discutir com Descartes". Todo mundo fica intimidado - "Quem sou eu pra discutir com Descartes?" -, mas ele abria essa possibilidade. O trabalho da filosofia tem que despertar no aluno esse gosto pela reflexão, esse entusiasmo. Eu estudei Rousseau, mas o Rousseau para mim é uma ferramenta para pensar a política; eu não faço um trabalho estrutural da obra do Rousseau, não fico na minúcia, nos manuscritos (nessa versão, ele fez isso; naquela versão, ele fez aquilo), é muito mais uma ferramenta, assim como Locke, Hobbes, Maquiavel, Aristóteles, Platão, Cícero. Estamos num mundo totalmente diferente, mas eu uso como ferramenta, não como objetivo final.

Humanidades em Diálogo: Em uma disciplina do curso de Filosofia, o senhor passou um trabalho sobre Rousseau no qual pedia ao aluno para comentar as teses desse filósofo e, a partir disso, pensar a situação da sociedade. É uma proposta incomum para o curso. 
Milton Meira: Sobre essa questão da avaliação, eu acho que dar uma prova para repetir o que foi dado no semestre funciona no Ensino Médio, Fundamental, mas na universidade não faz sentido. Pedir um trabalho é melhor porque o aluno vai se esforçar para refletir sobre o tema. Mas para o aluno é muito difícil pensar a situação da sociedade atual a partir de Rousseau, porque não está acostumado a fazer isso. $\mathrm{O}$ ambiente acadêmico está muito ruim, há uma desconfiança dos professores em relação aos alunos, acham que os alunos vão copiar da internet. Além disso, não há um contato efervescente com outras áreas, e os estudantes são muito dependentes do que manda o figurino: a instituição pede, você faz. Os estudantes têm a responsabilidade também de começar a arejar esse espaço. A universidade tem que ter vida universitária, e vida universitária é muito mais debate do que um número imenso de aulas, que o aluno tem que frequentar pela obrigação de obter créditos. Um professor pode dar uma aula brilhante, pode ser um ator dando aula, mas às vezes sobra muito pouco disso para o aluno. Quando o aluno passa um tempo lendo e depois vem pra um espaço de discussão, é outra história. O trabalho sério de leitura é mais importante. Mas vida acadêmica, no caso da filosofia, é tempo de leitura e de exposição do que leu, de discussão do que leu.

Para mudar essa situação, é preciso mudar a estrutura de universidade que cada vez mais se formaliza, fica mais engessada. Tem comissão para isso, comissão daquilo, de modo que o professor faz mais burocracia do que qualquer outra coisa, o que não é exatamente o objetivo principal do curso. A burocratização da universidade mata toda e qualquer possibilidade de criação. Certamente têm lugares em que os professores são mais atentos a essa criação, por exemplo, em laboratórios, na área de tecnologia as pessoas têm mais privacidade de criação. Na faculdade de Filosofia, nós temos uma espécie de grande escola de segundo grau, a sensação que eu tenho é essa, e não só na Filosofia, na Letras, Sociologia, História, Geografia... Um grande "colegião" no qual o aluno comparece só para cumprir carga horária, mas não tem interação, não tem vida universitária, só tem vida universitária nas festas, para tomar cerveja, não é assim? É a sensação que eu tenho, pode não ser a de vocês. Não há uma vida acadêmica forte, efervescente que precisava ter. Esse processo dos estudantes criarem espaços de eventos e discussão é super interessante porque os centros acadêmicos viraram apenas promoção de festas. A prática do debate iria quebrar um pouco essa estrutura muito individualista da pesquisa no Brasil. O pesquisador é um solitário, não conversa com ninguém, no máximo conversa pouquíssimo com seu orientador. Essa solidão da pesquisa é uma coisa muito estranha, no caso da Filosofia é um mote, porque é claro que tem 
que haver pesquisa, mas é necessário ter espaço de conversa. Existem muitas bobagens na Filosofia: "Eu estou fazendo alguma coisa e não posso dizer para ninguém, senão vão roubar minha ideia”.

\section{Humanidades em Diálogo: Já foi melhor?}

Milton Meira: Já foi melhor, mas essa coisa de roubar ideias sempre houve (risos)! Quando você se expõe, fica mais fácil de ter sua ideia roubada, mas não se trata de roubar ideias, nós estamos trocando ideias. Nesse ponto, o clima acadêmico poderia ser muito melhor. Mas isso se a universidade fosse aberta para o novo, em termos de dar uma contribuição também para a sociedade, porque qual é a função social da universidade? Qual á a nossa contribuição? Temos várias contribuições. Há algum tempo, as pessoas achavam que contribuir para a sociedade era cada um, por exemplo, participar da Campanha do Agasalho para a favela São Remo, já que está perto da USP. Mas isso é um absurdo, qualquer cidadão pode participar de quantas campanhas quiser para ajudar os pobres, isso faz parte da cidadania. Agora, a função social da universidade não é produzir conhecimento de ponta em todas as áreas do saber para a própria sociedade? Não é repetir o que já está posto, repetição do saber: "Eu passo para você o que eu aprendi a respeito de Rousseau, tenho vários discípulos rousseauistas dispostos a fazer uma coisa que eu já fiz." Não tem nada de novo, qual é a reflexão nova para a sociedade brasileira? A faculdade de Filosofia já foi muito mais forte, já deu Sérgio Buarque de Holanda, Florestan Fernandes, Antônio Cândido, o Cruz Costa... Havia uma série de autores que não ficavam fazendo "trabalhinhos de mudo", mas davam contribuição maior à história das ideias no Brasil porque tinham essa ousadia de sair um pouco mais da mera repetição. O Porchat, uma vez, já falou que tinha essa preocupação. Vocês conhecem o Oswaldo Porchat? Ele foi meu professor, ele tinha essa ideia de fazer à maneira dos franceses a análise estrutural do texto, ou seja, você pega um texto e vai no encadeamento das razões internas da obra. Os franceses faziam isso, como um passo para depois fazer uma análise da cultura nacional. O Porchat falou uma vez: "É, nós exageramos na dose. Nós insistimos tanto que devia se fazer uma leitura rigorosa do texto, que os alunos acabaram só fazendo isso, nada mais do que isso. Essa leitura rigorosa do texto é o passo inicial para que você possa ser um crítico de cinema, um crítico de arte, um crítico da história, da sociedade, da sociologia, um crítico das ideias, no caso da Filosofia. Você trabalha o texto como ferramenta da reflexão, mas não o toma como objeto final, senão você fica só fazendo trabalho miúdo". Naquela época, o Porchat fez aquele texto "Filosofia do senso comum", ele 
começava a se permitir refletir sobre coisas diferentes. O próprio Gianotti e a Marilena ao mesmo tempo que têm um trabalho estrutural, têm também uma proposta que é muito mais ampla de reflexão e ousadia. Só que ao sair da reflexão miúda, o filósofo se expõe também a receber tapas. Quando se refugia num autor, ele está protegido, claro, "Essa aqui é minha área, eu a conheço como ninguém, sou um dos maiores especialistas do mundo, ninguém vai me contestar”. Agora, quando a conversa diz respeito a coisas não pertencentes a sua área, mantém-se na repetição e nada mais de interessante é dito. Os alunos de Filosofia já ficam preocupados: "Eu não vou falar nada sobre isso porque não tenho capacidade para refletir, eu não entendo. Agora do Platão, eu sei falar" (risos). É interessante isso, que os próprios alunos começam, depois de certo tempo, a se policiar uns aos outros e dizer: "Ah não fala besteira, isso é bobagem, você tem que ler mais para falar, vai estudar para falar direito."

\section{Humanidades em Dí́logo: O senhor acha que a mudança do curso de} Filosofia da Maria Antônia para a Gidade Universitária afetou muito o ambiente acadêmico?

Milton Meira: Não, acho que não. A repressão da ditadura foi o primeiro impacto, quando tivemos vários professores cassados e o ano de I969 foi completamente morto aqui. Eu fiz a graduação praticamente sozinho, mais como um autodidata do que frequentando o curso. Assistia às aulas de vez em quando e estava tudo desmantelado e aí veio os barracões lá embaixo, onde tem a Psicologia. Não era como hoje, tinha os barracos que quando chovia ninguém escutava o que o professor falava, era um barulho infernal da chuva naquelas telhas de amianto, um barulho infernal. Mas, então, nos meus quatro anos de filosofia (I968-I97I) foi tudo muito precário. Na prática, a gente já tinha uma estrutura pra desenvolver a filosofia por conta própria. Tanto assim que, quando entrei na graduação, fiz um exame oral e eu já tinha lido Husserl, Descartes. No cursinho do grêmio a gente tinha visto toda a história da filosofia e foi lá que eu desenvolvi essa ideia de discussão, essa coisa que estava sempre presente nesse momento muito difícil. As pessoas se reuniam às vezes na casa de um, na casa de outro. Às vezes para discutir política e para discutir também os textos que estavam sendo desenvolvidos na sala de aula. E quando um ou outro ia preso, desaparecido, então, sei lá... era um momento complicado. Eu sinto falta desse espaço de debate, os professores hoje também não têm, nós tínhamos antes. É preciso deixar claro que, com a ditadura, o pessoal se dispersou ou acabou não mais se encontrando. O pessoal de teatro, o [Augusto] Boal, o Jean Francisco 
Guarnieri, o José Celso [Martinez Corrêa], que é amigo do Salinas, se reunia com muita frequência, então a filosofia passava sempre pelo teatro, cinema e isso se perdeu completamente. Mas em parte devido a essa dispersão da ditadura e não se recompôs mais, de modo que hoje cada um está fazendo seu trabalho individual, solitário. E essa forma de comunicação e o debate mais vivo foram se perdendo. Agora para recuperar isso é um trabalho difícil, não é fácil recuperar o hábito de discutir, estar aberto ao debate com outras áreas. E hoje também tem muito preconceito. Você vai fazer o debate, mas com quem vai discutir? Se você convida alguém fundamental de direita, não pode. Vai conversar com o pessoal da faculdade de direito, não pode porque lá só tem gente da direita. Não é assim? Isso já naquela época. Então você tinha uma série de preconceitos e aí que a esquerda foi se fechando também. A faculdade de filosofia virou um gueto, muito autocentrado. Tem coisas acontecendo, mas que acontecem fora da ordem institucional acadêmica. Mas poderia acontecer muito mais, a sociedade civil tem que pegar pesado. Tem que começar a se organizar.

Humanidades em Dí́logo: O senhor poderia falar um pouco a respeito da Discurso Editorial e do Jornal de Resenhas? Qual a importância dessas publicações?

Milton Meira: Isso foi uma das loucuras da minha trajetória. Eu sempre pensei que todo o saber que a gente produz na universidade não podia ficar intramuros, tinha que ser publicado para que as pessoas pudessem ler. A Discurso Editorial surgiu em I993 na ocasião em que eu tinha terminado dois mandatos na chefia do departamento e a revista estava com vários números atrasados por falta de recursos. Não tinha dinheiro para editar a revista Discurso do departamento, então, reuni o pessoal e falei: "Vamos criar uma editora, ou uma associação" e criamos a Discurso, uma associação editorial sem fins lucrativos, que tem por objetivo editar os livros de Filosofia e de áreas afins. A ideia era fazer cursos, vídeos, ter uma produção imensa para marcar a presença do departamento de Filosofia no cenário nacional. Então nós começamos a fazer alguns textos interessantes, procurei colocar em prática a ideia de sociedade civil, que já estava presente desde essa época, por que não criar então uma associação dos professores do departamento de Filosofia que tenha projetos para desenvolver? Nós fomos correr atrás de recursos. Só que, qual foi o erro que eu cometi naquela época? Bom, não foi de fato um erro. É erro se levarmos em conta a estrutura burocrática da universidade. Como é uma associação de professores, ela não pode ter recursos da universidade, então 
tem que procurar iniciativa privada ou em outras áreas estatais, mas da USP, não. Então, corri atrás de recursos, e atualizamos a revista Discurso, os quatro números ficaram em dia desde o volume de 1994 e permanecem em dia atualmente. A primeira mobilização de recursos foi essa, depois nós começamos a fazer livros, procuramos Fapesp, CNPq, verbas de outras instituições, mas a dificuldade era muito grande porque a gente teria que viver só da venda de livros acadêmicos, o que significa falência. Se fossem livros de autoajuda, livros religiosos, livros de devoção, a situação seria outra, estaria rico.

Em I993, num dos números da Discurso, lá na fundação, eu tinha feito um pequeno texto que está, aliás, no número I9 da revista: o objetivo da Discurso Editorial é, dentre outros, criar também um jornal de resenhas. Passaram-se dois anos até que fizemos o projeto do Jornal de Resenhas. Aí, na hora de escolher o nome... as pessoas comentavam: "e o nosso jornal de resenhas, sai ou não sai?". Todo mundo colocou na página duzentas opções de títulos, ninguém gostou de nenhuma. Então falei: vai ficar Jornal de Resenhas mesmo. Na época, tivemos um início interessante, eu fui procurar o Otavio Frias que era o filho do velho Frias, que tinha feito curso de Filosofia aqui também e achou interessante o projeto. Eu falei para o Otavio: "Eu gostaria que fosse publicado na Folha e, se a Folha não quiser, vou procurar o Estadão pra ver se eles assumem um campo." Aí, ele: "Não, pode deixar que achamos interessante e vamos tocar”. Então, durou lá até 2004, saiu encartado na Folha de São Paulo e nós íamos na redação para fazer o jornal. Mas, quando houve a crise na Folha pela compra do Uol, não deu mais pra manter o jornal, porque o sindicato dos jornalistas fez pressão pra cortar. Eles queriam que o Jornal de Resenhas saísse na Folha online mas a comissão editorial não concordou, então continuamos tentando viabilizar a publicação e voltamos em 2009 com o apoio do MEG, na época em que o [Fernando] Haddad era ministro, e permanecemos com esse apoio até 20IO. Em 20II tentamos retomar pelas assinaturas e até hoje estamos tentando ressurgir, com muita dificuldade. Estamos querendo mudar nossa forma de organização da sociedade sem fins lucrativos, mudar pra OSCIP. OSCIP é uma entidade que foi criada pela Ruth Cardoso, que era antropóloga aqui da USP e foi esposa do Fernando Henrique Cardoso. Ela criou em I998-99 uma legislação para a sociedade civil se organizar e poder ter parcerias com o Estado, sem problema nenhum. É uma legislação que ficou perdida no tempo e nisso a Discurso já existia. Talvez, a gente faça isso pra viabilizar o Jornal de Resenhas e outros projetos. A revista Discurso e o Jornal de Resenhas são projetos da Discurso Editorial. Eu ainda tenho esperança de tornar a Discurso Editorial uma grande editora, para continuar um projeto igual àquele que foi o da Coleção Pensadores. 
A OSCIP tem interesse público, além disso tem agilidade para criar títulos de filosofia sem depender da editora da USP. Quando criamos a Discurso Editorial houve um certo mal-estar porque a USP não poderia ter outra editora além da EDUSP. Então, para a Discurso sair precisamos criá-la fora da estrutura jurídica e burocrática da universidade. Por isso ela foi feita como se fosse uma associação, em vez de ser uma associação sindical, é uma associação cultural e editorial dos professores e, como tem professores, não pode ter recurso da universidade. Todos os professores aderiram ao projeto. Depois eu fui chamado para estar à frente da editora Humanitas, à qual dei um estatuto parecido com o da Discurso, e continua existindo até hoje, mas também é difícil de sustentar porque tem essa vida difícil, ela pertence, mas não é assimilada pela estrutura jurídica e administrativa da universidade, tem que funcionar fora.

$\mathrm{Na}$ época também muitos estudantes acharam que ao fazer a Discurso eu estava criando um projeto privatista da universidade. É uma visão completamente equivocada, você está mobilizando a sociedade civil para projeto de interesse público, não é de interesse privado, privatização é outra história, você vende a USP para um grande grupo americano ou coisa assim. Mas criar projeto de instituições de interesse público, que sejam universitários de interesse público, isso é necessário fazer. Naquela época não se convivia bem com a ideia das fundações, nas quais havia muita corrupção. Por isso criamos uma associação muito pequena que é como se fosse um CAF, só que tem CNPJ, tem tudo, emite nota fiscal, tudo dentro da legalidade, não tem fins lucrativos, então não pode ser acusada de privatização. Mas são projetos interessantes porque, a ideia central é fazer com que o saber produzido na universidade seja um saber mais socializado, exposto pra sociedade.

No Jornal de Resenhas, as resenhas são feitas por especialistas de cada área e o Jornal é muito pequeno para a produção editorial brasileira, teria que ser uma revista bem mais grossa. Mas pra isso tem que ter dinheiro pra fazer. Alguém na época poderia dizer: "Nós podemos fazer isso funcionar dentro da universidade”, mas se eu fizesse dentro da universidade não sairia porque começou a haver muito jogo político. Quem vai ser o pai da matéria, não é? É o diretor que vai assumir? Ou tem uma campanha política? Você vai pôr esse projeto como bandeira de campanha? É um absurdo, não é, mas aí morreu a ideia. Eu não vou colocar um projeto que eu já sei que vai nascer morto porque vai estar envolvido num jogo político da própria academia. Vocês conhecem o New York Review of Books e London Review of Books? São jornais que têm apoio das editoras, vivem de assinaturas e fazem resenhas de tudo que sai no mercado editorial londrino e nos Estados Unidos. Na França tem a Magazine Littéraire. 
Então, eu queria fazer uma coisa igual no Brasil. E é interessante, se vocês conhecem as publicações do Jornal de Resenhas... Vocês conhecem? Aqueles três volumes? Se eu olhar quem foi que contribuiu com o Jornal, foi toda a intelectualidade brasileira, ali tem: Aziz Ab' Sáber, da geografia; Antônio Candido; Guido Mantega; Gelso Furtado, várias figuras importantes, uns seiscentos intelectuais brasileiros e todos de primeira linha. É um projeto que, se a gente conseguir sensibilizar agora para a formação de uma OSCIP - o peso que ele construiu ao longo da história foi muito forte - poderá emplacar. Comecei também a produzir pela Discurso e pelo departamento livros didáticos para o Ensino Médio, quatro já estão prontos... E qual foi a minha decepção? Era para ter saído em outubro do ano passado e na hora de imprimir... foi preciso abrir uma licitação. E então parou, já tem um ano que não sai. Isso mata qualquer um. Essa fome enterrada, do ponto de vista administrativo e jurídico, mata muito a iniciativa, porque, poxa vida, eu fiz um projeto com tanto prazer e tinha trinta livros para publicar. Se começar com quatro já vai ser interessante e a turma já vai se entusiasmar, mas tem que entrar no processo licitatório e, então, vai levar uns dois, três anos pra sair. Se eu tivesse feito o Jornal de Resenhas pela instituição não ia sair nunca. Então, a Discurso vai ter sempre que andar pelas próprias pernas, quando ela tenta trabalhar com recursos do departamento, a Discurso não ganha dinheiro, mas o departamento está assumindo como parceiro, ela vai ser do departamento. Mas aí é tudo muito emperrado, muito difícil de tocar e desanima. Agora se for uma organização mais bem estruturada, vai se encaminhar bem. Mas a ideia é fazer com que o saber universitário seja um saber mais partilhado pela sociedade que paga a universidade, então a gente pode produzir reflexões sobre os livros e divulgar o que pesquisamos aqui. A EDUSP poderia ser essa editora, poderia ter uma face de direito, uma de filosofia, de história e geografia, química, de ciência da saúde etc. Ela poderia contemplar tudo isso, pois é uma grande editora, como a Presses Universitaires Française (PUF) faz isso. Mas, para isso, precisa ter cabeça para fazer, mas como tudo é emperrado na cabeça do reitor não sai muita coisa, não é?

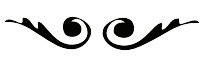

